\title{
STUDY REGARDING THE PERCEPTION OF THE CSR CONCEPT AMONG THE ALBA IULIA ENTERPRISES
}

\author{
Silvia Ştefania Mihalache ${ }^{1}$ \\ Filimon Stremţan ${ }^{2}$
}

\begin{abstract}
Although several years ago people rejected the idea of corporate responsibility, today CSR is a concept directly related to sustainable development, competitive companies, to modern firms. But unfortunately, in Romania companies still have several years to catch the European modern enterprises from the member states.

The aim of this article is to emphasize the fact that the majority of the firms from Alba Iulia still do not know what CSR concept mean. In order to demonstrate that we applied a CSR questionnaire on 111 firms from Alba Iulia and analyzed their answers.
\end{abstract}

Key words: corporate social responsibility, Alba Iulia enterprises, sustainable development

JEL codes: $M 14, Q 01$

\section{Introduction}

Corporate Social Responsibility, a concept that has no world accepted definition, starts to be adopted by the Romanian firms as well. Just like the other companies from all around the world, the Romanian enterprises realize that it is not enough to use only the profit maximization policy, you also need to adopt a social responsible behavior.

The aim of this article is to demonstrate that, although the CSR concept is used also in Romania, the majority of the firms still don't know what the CSR concept really means. This is the result that we obtained after analyzing the $111^{\text {th }}$ questionnaires we applied on the Alba Iulia firms.

The article starts with a short presentation of the CSR concept in old times and goes on with a presentation of the actual perception of the same concept. For these two parts we used information from authorized sources and bibliographic materials from the internationally recognized databases.

After the presentation of the CSR concept we start to analyze the data we have obtained from applying the questionnaires. The result of this research demonstrates our supposition: CSR is still little known in Romania. It seems that all large companies from Alba Iulia use strategies and policies that include CSR activities, but it would be a lie to say the same thing about the other firms.

\section{CSR in old times}

For decades, some people rejected the idea of corporate responsibility. Milton Friedman called it a "fundamentally subversive doctrine" in a free society, adding: "There is one and only one social responsibility of business - to use its resources and engage in activities designed to increase its profits." (Financial Times)

In old times people used to say that: if managers wished to support other causes they should do so in their own time and with their own money. And there were many which supported this view. The shareholder value movement, which argued that a company's sole responsibility was to produce a decent return for its owners, was based on it.

\footnotetext{
1 “1 Decembrie 1918" University of Alba Iulia, Faculty of Science, Management-Marketing Department, sylvia_mihalache@yahoo.com

2 "1 Decembrie 1918" University of Alba Iulia, Faculty of Science, Management-Marketing Department, filimon_stremtan@yahoo.com
} 
The champions of corporate responsibility never denied the importance of either profit or shareholder returns. But they insisted that responsible companies would produce more of both.

In 1986, newspapers wrote about Prince Charles's support for the Per Cent Club, a group of UK companies that promised to donate half percent of pre-tax profits to community causes. Stephen O'Brien, then chief executive of Business in the Community, which administered the club, said the companies were not promoting healthier local communities out of philanthropy, but as a way of expanding their consumer markets.

The idea that companies would do better financially if the people around them were wealthier was not new. In 1914, Henry Ford introduced a daily wage of $\$ 5$ so that his workers could afford to buy the cars they built. Many later supporters of corporate responsibility extended the argument to the community as a whole: the better people were the more of the companies' products they could buy.

There were other business arguments in favour of corporate responsibility, also. Employees who helped local schools or supported art projects would feel happier about their companies. Staff loyalty would increase. Productivity would rise.

Most important, the wider community would regard companies as contributors to society, not exploiters. Customers would stick by them in times of trouble. Winning this social acceptance, often called "a license to operate", was sensible risk management, and therefore a legitimate business objective.

The Friedman view still has its proponents but the financial crisis has reduced to silence many of them. The blind pursuit of shareholder value was blamed for bringing the banking system down. Even Jack Welch, former General Electric chief executive and one-time champion of shareholder value, denounced it as the "dumbest idea in the world".

By that stage, however, corporate responsibility had changed. Globalization and competition from lower-cost countries had placed the old idea of nurturing local communities under great stress. To survive, western companies moved manufacturing lines abroad. Many of those loyal employees were thrown out of work and those once-nurtured neighborhoods abandoned.

Some companies adopted a new approach: sustainability. They said that reducing packaging, lowering petrol consumption and using less electricity and water helped to preserve the planet and significantly cut costs.

It seems that for some people sustainability produces the happy marriage between profitability and a clearer conscience that champions of corporate responsibility have so long sought.

But, the old forms of community engagement will not disappear. They fulfill deep human needs - to be respected and to feel that one is doing something worthwhile. It is said very well that people should do this in their own time; much of their time is spent at work.

True corporate responsibility, sustainability and that treasured "license to operate" come above all, from identifying the fundamental dangers to the business and ensuring they don't come to pass.

\section{The actual CSR concept}

The European Commission's definition of CSR is: "A concept whereby companies integrate social and environmental concerns in their business operations and in their interaction with their stakeholders on a voluntary basis" (pe site-ul official al UE). Corporate Social Responsibility is part of the Europe 2020 strategy for smart, sustainable and inclusive growth, says the same Commission.

Another generally accepted definition for CSR is the one given by the Dow Jones Sustainability Indexes: "An approach by which a company: a) recognizes that its activities have a wider impact on the society in which it operates; and that developments in society a turn impact on its ability to pursue its business successfully; b) actively manages the economic, social, environmental and human rights impact of its activities across the world, basing these on principles 
which reflect international values, reaping benefits both for its own operations and reputation as well as for the communities in which it operates; c) seeks to achieve these benefits by working closely with stakeholders and other groups and organizations - local communities, civil society, other businesses and home and host governments" according to some CSR sites.

CSR initiatives of different organizations do not represent something new at European level. Yet, the actual concept of CSR is different from the initiatives from the past through managing in a strategic manner and developing the necessary instruments in this.

The current concept of social responsibility, however, differs from past initiatives by a strategic management and development tools necessary for this purpose.

"Corporate social responsibility" refers to a company's duty beyond the technical requirements of national laws and regulations to comply with global principles of human rights, fair labour, environmental protection and corruption-free management (Financial Times, Scheffer, 2010).

According to The World Business Council for Sustainable Development "Corporate Social Responsibility is the continuing commitment by business to behave ethically and contribute to economic development while improving the quality of life of the workforce and their families as well as of the local community and society at large."

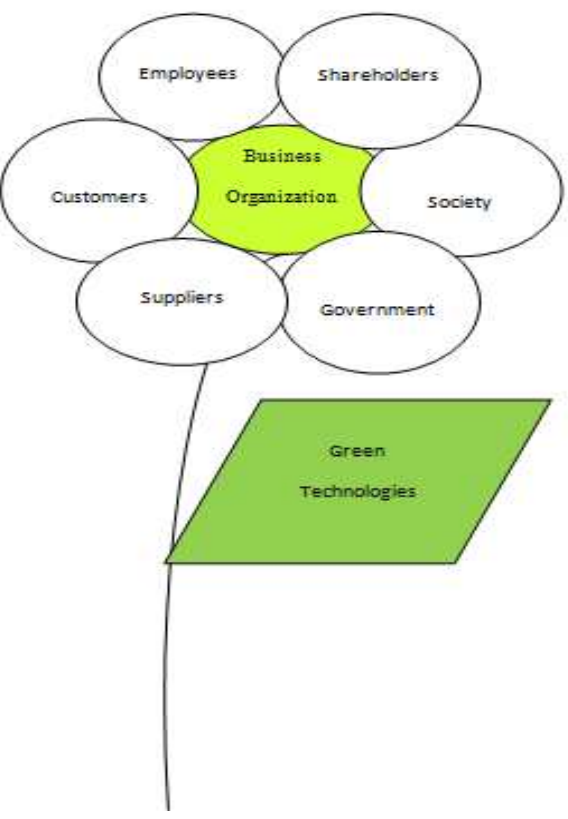

Fig. no. 1 - A representation of Corporate Social Responsibility

Source: Author's contribution

For years, British Petroleum has promoted its "green" credentials to the point of transforming its logo, advertising and website into celebrations of the environment. The public relations division trumpets the company's commitment to human rights and fair labor standards. Like some other companies, BP issues annual sustainability reports attesting to its compliance efforts in these fields. But BP's catastrophic gusher shows how corporate hype can peddle an illusion at the expense of the oceans. In Romania, the main example, in the same sector is Petrom, a company that invested a lot in social responsible image, in campaigns for "green something" or in smart children and so on. Some people suggest that all this effort companies do through social responsibility is only a diversion in order to attract the public attention from the impact of the petroleum upon the environment.

Both the two British and Romanian companies annually publish a report on their social responsible activity. 


\section{Study regarding the perception of the CSR concept by the firms (companies) in Alba Iulia}

The present paper represents a small research on the position the Firms (companies) in Alba Iulia have towards the concept of CSR. In order to materialize this small research, 111 questionnaires have been applied at firms (companies) in Alba Iulia. Their activity field is very different, the questioned firms managing all kind of economic activities, starting with selling building (construction) materials and going on with selling banking or touristic services.

Analyzing the information obtained from the questionnaires applied on companies in Alba Iulia we reached the following conclusion: more than a half of the interrogated firms (companies) did not know what Corporate Social Responsibility concept actually represents. This makes us think (believe) that once again it is proved that the position of the Romanian society is way behind other European and even international ones.

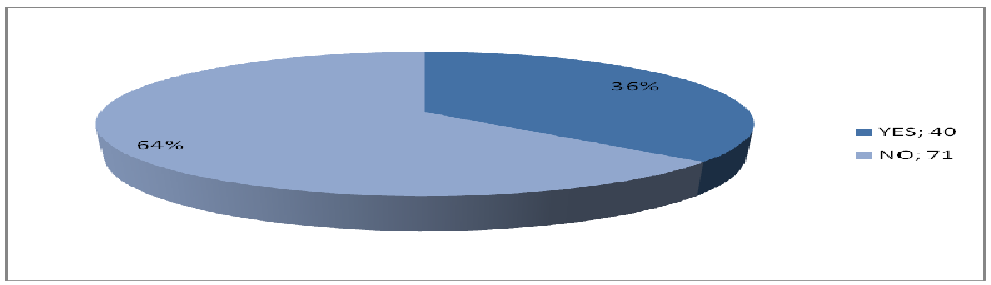

Fig. no. 2 - The percentage of the firms that know the meaning of Corporate Social Responsibility concept

As we have already mentioned, the companies surveyed belong to both categories: micro enterprises and SMEs. Thus, from the 111 firms, 71 are micro enterprises, 25 are small enterprises, 11 medium enterprises and 4 large enterprises. Unfortunately we would say, from all these, only 22 micro enterprises representing 31\%, 10 small enterprises representing 29\%, 4 medium enterprises representing $27 \%$ and 4 large enterprises representing $100 \%$ of the questioned firms know what the CSR concept means.

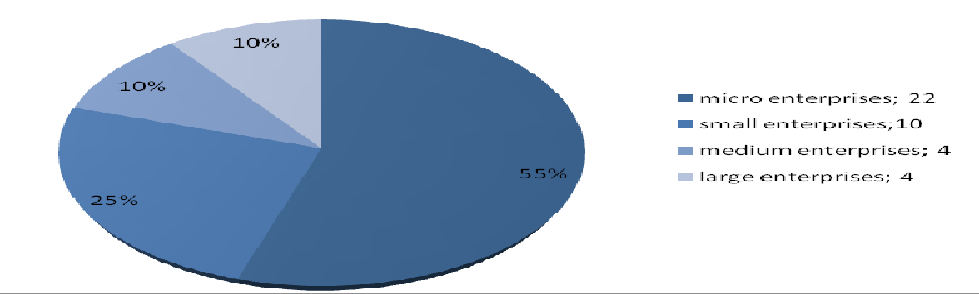

Fig. no. 3 - The distribution of the firms that know the meaning of CSR concept

In a world where most often the Internet represents the main instrument of modern firms for promoting, selling and marketing, these practices are still relatively little used in Romania. The best proof for this is the percentage of firms that have a web page. So, in our case, 33 firms have a web page (11 micro enterprises, representing 13\%, 11 small enterprises representing 31\%, 7 medium enterprises representing 39\%, and 4 large enterprises representing 100\%). Thus, we can conclude that most micros operate in the classic manner without using modern means of promoting, selling, trading, while large enterprises, all of them have a website, and more recently, some of them begin to post on their web pages data related to their social responsible activities.

For example, a large firm producing ceramic products mentioned on its website that it has adopted "a unified approach of all activities, in order to assure products' quality, the increase of customers' satisfaction and continuous improvement of organizational performance. The company 
currently offers products and services that comply with the requirements regarding health, safety, environmental protection at European or international level" according to Apulum company. It is easy to understand that having no webpage is mainly due to the firm's size; the greater it is the more opportunities to purchase a virtual space and maintain it are. It is also true that a smaller firm cannot perform important activities of social involvement on such a large scale to be proud of.

A micro-enterprise will not be able to sustain campaigns like those promoted by Petrom the largest Romanian oil and Gas Company, with activities in various areas such as: Exploration, Production, Marketing, Refining and Petrochemicals. This company claims that: "Corporate Social Responsibility is part of Petrom's strategy. In this way, we want to make sure that we fulfill the responsibility towards society through programs that generate not only long-term results, but attitude also. First of all, we want every employee of our company to have a social responsible behavior and to improve our business practices by strengthening the Corporate Governance Policy. Meanwhile, being the largest company in Romania, Petrom is actively committed to contribute to the development of Romanian society. By this we understand making a long-term contribution to creating a better world, both for present and for future generations. This way, we show $<<$ Respect for future! >>. And this is the main reason why we choose this name for our CSR campaigns" according to www.responsabilitatesociala.ro.

The same Internet that offers companies the opportunity to use the time spent for promoting or selling products in a more efficient manner, represents also the main route through which the concept of Corporate Social Responsibility became known by the companies in Alba Iulia. Thus, for the question on the way that companies first learned about CSR concept, 18 firms have chosen the Internet as answer, 12 have chosen the relatives and 10 have chosen the TV as answer. This may suggest that the Internet remains, at least for now, the fastest way to disseminate information and Information Technology, along with its advantages and disadvantages, remains the "piece de resistance" of the century we live in. Another example that confirms this is the fact that Luisiana Oil $\&$ Tire withdrew from the field all the sales agents and put them to deal with telemarketing. The result, selling expenses decreased $10 \%$, while sales volume has doubled (Porter, 2008).

As for the meaning of the CSR concept for the questioned companies, we conclude that the main components of CSR from the point of view of the companies in Alba Iulia are (listed according to their frequency in the questionnaires applied):

- $\quad$ Benefits for everyone involved;

- $\quad$ Developing relationships with employees and customers;

- Environment protection and conservation;

- $\quad$ Establishing partnerships with local communities;

- $\quad$ Obtaining the competitive advantage;

- $\quad$ More donations and charity;

- $\quad$ Quality products;

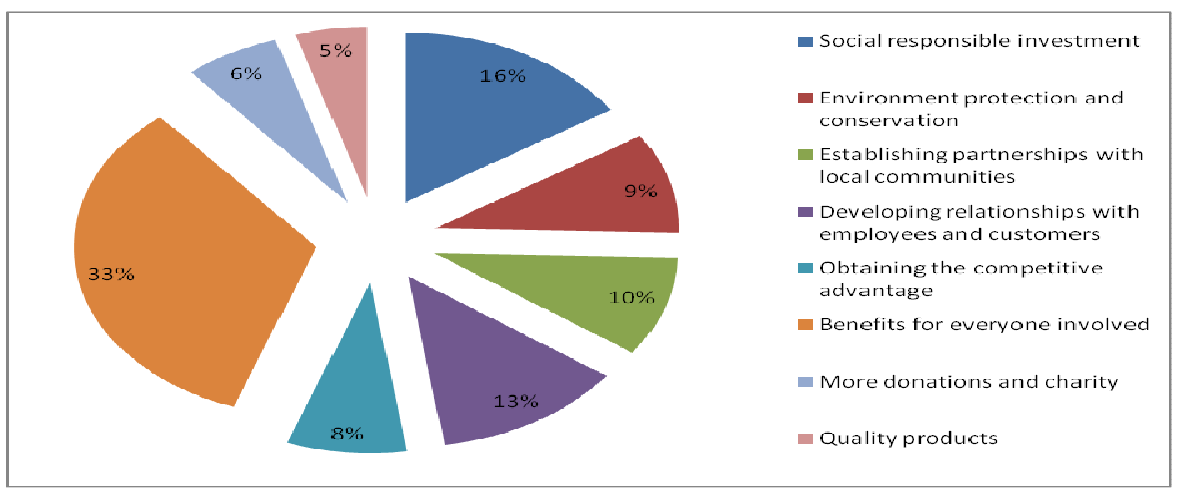




\section{Fig. no. 4 - The most representative "definitions" the questioned firms gave for CSR}

From the above figure we can see that for most representatives of the questioned companies, CSR primarily represents "Benefits for everyone involved", then "Social Responsible Investment".

The involvement in social programs or projects' development represents another sensitive issue on which the representatives of companies had to respond. From those who knew the meaning of CSR concept, nearly half of them responded in an affirmative way when asked about participating in social programs or projects' development. Among the main social involvement activities the companies mentioned in the questionnaires, we can specify: sponsorships, donations to churches, schools, NGOs, retirement homes, etc. As for their involvement in large social projects, most respondents believe that they have not aroused a great interest that will determine them to engage. Another feature emerging from the answers to this question is that mainly the firms that fit into the category of SMEs are those which have developed or are willing to get involved in social projects, most likely due to considerably higher. All large enterprises have responded affirmatively to the question with regard to the involvement in social projects. This shows that, besides the experience they have in their work area and the market position they have gained over time, they also benefit from the fact that they have more cash than SMEs. But, with all these they sometimes need to be made a visible part of the market, one way or another.

The main reasons for the other 22 companies for not ever being involved in social projects are: the lack of liquidity faced by most micro-enterprises in this period of economic and financial crisis or they were not asked to get involved in social activities, and starting a social project on their own was irrelevant for their activity field.

When asked if the company financially supports the training of their human resource, 22 firms answered yes, three answred no, and 15 refused to answer. From our point of view, these results seem somewhat odd given that, according to Labour Code: "Article 190 - (1) Employers are required to ensure participation in training programs for all their employees, as follows: a) at least once every two years, if they have at least 21 employees, b) at least once every three years, if they have less than 21 employees; (2) the expenses related to training programs, provided in terms of paragraph (1), is supported by the employers" according to labour legislation.

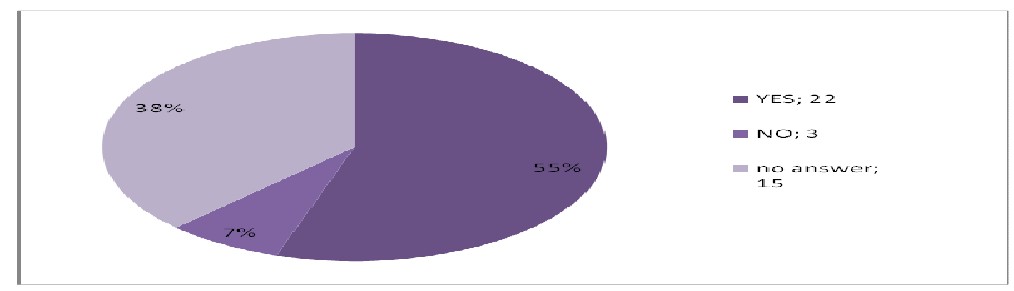

Fig. nr. 5 - Supporting the training of their human resource

The main method used for developing the company's human resource is training. The budget for trainings varies, depending on company's size, from 300 Ron/year for a micro enterprise, to $7500 \mathrm{Ron} / \mathrm{year}$ for a large-scale enterprise.

Another question to follow corporate social responsibility questionnaire was establish in order to find out if companies have a policy designed to save non-renewable resources. According to the questionnaires, a total of 17 companies, of those who know the meaning of CSR, have at company level a policy of saving resources that no longer regenerate. In order to accomplish that the companies use more new productive technologies that reduce the energy consumption and increase productivity, while reducing working time and raw material wastage. A relevant example is a furniture workshop that uses wood waste to produce heat during the winter, thus saving considerable sums that would be otherwise wasted on gas. 
At the same question 14 companies said they have no non-renewable energy saving policy, while the other nine firms declined to answer this question. These 9 companies are the same with those which refused to respond to the question which relates to environmental policy. Unlike saving policy questions in this case, 27 companies say they have a company-wide environmental protection policy, the number of negative answer being considerably lower, respectively four companies.

Among the measures taken by companies in order to reduce the environmental impact of their activities we mention:

- $\quad$ Collecting waste oil, car batteries;

- Environmental protection by using "Rabla Programme";

- $\quad$ Contracts with recycling companies;

- $\quad$ Organic waste collection;

- $\quad$ Plastic bottles and cardboard collection;

- $\quad$ Sponsorship of various ecological activities;

- $\quad$ Collecting printer cartridges and paper for recycling;

- $\quad$ Maintaining cleanliness at workplace, and around the Unit;

- $\quad$ Collecting by types of waste and take them to recycling companies;

- $\quad$ Replacing conventional furnaces with rapid combustion furnaces;

- $\quad$ Closing the industrial waste deposit;

- $\quad$ Collection, recovery or disposal of generated waste;

- $\quad$ Old car reduction;

At the same time, 31 of 41 companies sustain the using of clean technologies, but, unfortunately only 18 of them use it.

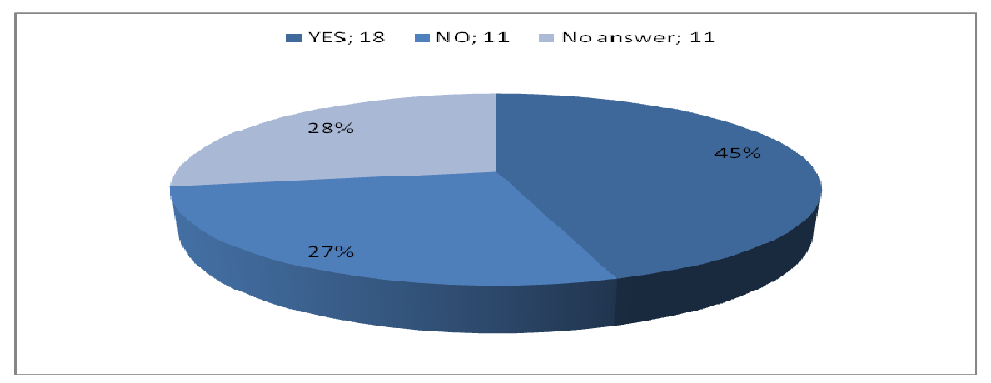

Fig. no. 6 - The percentage of the firms that use clean technologies

Clean Technologies are technologies that:

- Use energy, water and raw materials and other inputs more efficiently and productively;

- Create less waste or toxicity;

- Deliver equal or superior performance;

- Improve customer profitability, through cost reduction and/or increased revenues.

Such technologies are found in a broad range of industries, including energy, water, manufacturing, advanced materials, and transportation. Examples of Clean Technologies are wind and solar energy, water filtration, industrial process controls and hybrid electric vehicles.

Given the environmental benefits these technologies confer, Clean Technology is an intrinsic part of a Sustainable Economy. This is the reason why all the firms from all around the world should use them.

\section{Conclusion}

CSR, a concept that still does not have a world recognized definition, remains an unknown quantity for the most Romanian companies. This is the main conclusion we got to after analyzing the data from the questionnaires applied on 111 firms in Alba Iulia. It is imperative that all the firms 
should adopt the CSR concept in their company strategies and policies in order to leave for the generations to come a living world.

In the same time, firms should realize that profit maximizing policies are not enough for becoming competitive. It requires for companies to involve in society in order to make themselves visible, to show respect towards the society and the environment they live in. the companies must be aware that they have to take care of their employees, of the environment, of the raw materials they use, of their consumers. Every company is part of the ecosystem and if she is not aware of this soon she will not be competitive. Also, an irresponsible use of the planet's goods will take us in the situation of not having any other renewable resources and the next generations will therefore disappear.

CSR is also used by many companies, including Romanians, as a means to promote, part of the marketing strategy of the firm, often mixing up the annual CSR reports with the promoting brochures, but this is another topic that will make a subject to a future research.

\section{References:}

1. Basaraba A., Stan L.-M., 2009. Responsabilitatea socială corporatistă în contextul crizei economice globale- GeoPolitica. Revista de Geografie Politică, GeoPolitică şi Geostrategie, Anul VII, nr. 29.

2. Coors, A. C.; Winegarden, W., 2005. Corporate Social Responsibility - Or Good Advertising?, Regulation, Vol. 28, Issue 1.

3. Dragolea L., Cotîrlea D., 2010. Benchmarking - a valid strategy on the long term, Annales Universitatis Apulensis Series Oeconomica from Faculty of Sciences, "1 Decembrie 1918" University, Alba Iulia.

4. European Commission, 2001. Promoting a European framework for corporate social responsibility - Green Paper, Office for Official Publications of the European Communities, Luxembourg.

5. European Commision,,A guide to communicating about CSR”, Directorate-General for Enterprise, available online at: http://europa.eu.int/comm/enterprise/csr/campaign/ documentation/index_en.htm;

6. Moisă C., Hinescu A., 2007. Marketing particularities for the services firms, MicroCAD International Conference, Miskolc University, Hungary;

7. Pendleton, A., 2004. The real face of corporate social responsibility, Consumer Policy Review, Vol. 14 Issue 3,;

8. Porter, M., 2008. Despre concurenta, Editura Meteor, Bucuresti.

9. Rof, L. M., Dănuleţiu D., 2010. Environmental accounting and corporate social responsibility, Conference proceedings - European Integration - New Challenges, Oradea.

10. Stremţan F., Mihalache S. Ş., 2010. Considerations on Social Marketing in Romania, International conference: Competitiveness and Stability in the Knowledge-Based Economy, Craiova, Romania;

11. http://www.responsabilitatesociala.ro/companii/petrom.html;

12. http://www.legislatiamuncii.ro/a/1794/codul-muncii--titlul-vi.html;

13. http://www.apulum.com/ro/index.php?id=10023\&lang=ro

14. http://www.ft.com/cms/s/0/ad0a651c-69ef-11df-a978-00144feab49a.html The definition we can find in Financial Times - BP (n. British Petroleum) shows the need for a rethink of regulation - By David Scheffer; Published: May 28 2010;

15. http://ec.europa.eu/enterprise/policies/sustainable-business/corporate-socialresponsibility/index_en.htm

16. http://www.article13.com/csr/definitions-1.asp\#CSR 
17. http://www.ft.com/cms/s/0/eba6a20a-8de3-11df-9153-00144feab49a.html (Financial Times - Responsible companies' first duty is survival - By Michael Skapinker; Published: July 12 2010) 